\title{
Performance Model Based on Market Knowledge, Product Knowledge, and Entrepreneurship Knowledge Case Study on Basic Food SMES in Sukabumi
}

\author{
"Ujang Setiawan ${ }^{1}$, Yusuf Iskandar ${ }^{2}$ \\ ${ }^{1}$ Department of Management, Faculty of Economics and Business, Universitas Indonesia \\ ${ }^{2}$ Department of Management, Faculty of Economics and Business, Universitas Indonesia \\ *Corresponding author. E-mail: ujang.setiawan_mn18@nusaputra.ac.id
}

\begin{abstract}
The MSMEs of necessities in Sukabumi Regency are quite fast both in sales and in their development. The researchers in this study aimed to find out how big the influence of market knowledge on the performance of MSMEs was, how much product knowledge affected the performance of MSMEs, find out how much entrepreneurial knowledge had on the performance of MSMEs, and whether the three had a very significant influence on the performance of MSMEs. The method used in this research is a survey method directly to the field by giving a questionnaire, while the data collection technique in this study is a questionnaire. The researchers conducted surveys and research in the Sukabumi Regency area with the targeted target being MSMEs with basic and small scale sizes. Researchers used a sample of 200 basic food SMEs with a sample comparison technique, in this study 12 indicators were converted into questions in a questionnaire with a total of 40 questions. The research data that has been obtained and obtained are then analyzed using the Structural Equation Modeling (SEM) method with the help of the Amos 23 and SPSS 23 software. The researchers in this study got quite good results because market knowledge, product knowledge, and entrepreneurial knowledge turned out to have a significant effect on The performance of MSMEs is proven by the value obtained, which is $47 \%$. These results have been tested for validity with SPSS software before being analyzed using Amos software so that this data has been declared valid.
\end{abstract}

Keywords: Market Knowledge, Product, Entrepreneurial Entrepreneurship, MSME Performance.

\section{INTRODUCTION}

Micro, Small, and Medium Enterprises (MSMEs) are one of the leading driving forces in economic development in Indonesia. The movement of the MSME sector is vital to creating growth and employment. MSMEs can create jobs faster than large business sectors. MSMEs are also quite diversified and make important contributions in exports and trade so that they become one of the supporters of the country's foreign exchange even though the contribution of MSMEs is much smaller when compared to the contribution of large businesses. [1]

Entrepreneurship can be defined as a new market and existing goods and services or newly launched companies. Entrepreneurship is creating unique products, one of which is a good product design and marketing strategy and has solutions to overcome problems to compete with other companies. An entrepreneur is a person who is ready to take risks and uncertainties to make profits and continuous growth by identifying opportunities that exist by combining resources to establish them [2]. One of the things that will encourage success in entrepreneurship is entrepreneurial knowledge which needs to recognize and create opportunities then action is taken to get the information that needs to be known related to entrepreneurship which can be obtained from information sources [3]. 
The basic food umkm is a business that is occupied by various educational backgrounds, ranging from those who have never attended school to those who have a bachelor's degree, but most of them have an equal education because in general this business is considered one of the dead ends for those who have low education. choosing a business compared to working with other people, therefore it is natural that many successful MSMEs do not understand and know much about market knowledge, product knowledge to entrepreneurial knowledge, therefore researchers want to do more research about the title above.

The purpose of this study is to provide empirical evidence to what extent market knowledge, product knowledge and entrepreneurial knowledge affect the performance of SMEs. The results of the study will provide output on the performance of micro, small and medium enterprises in basic food businesses in Sukabumi Regency. Thus, researchers have the impetus to conduct research systematically and scientifically on "PERFORMANCE MODELS OF SHOPPING SME'S BASED ON MARKET KNOWLEDGE, PRODUCT KNOWLEDGE AND ENTREPRENEURSHIP KNOWLEDGE (CASE STUDY OF SEBAKO MSMES IN SUKABUMI REGENCY)"

\section{LITERATURE REVIEW}

\subsection{Market knowledge}

In a company, there are many determining factors to achieve success, one of which is starting entrepreneurship as discussed in the title above, namely market knowledge, product knowledge, and entrepreneurial knowledge of entrepreneurs. Market knowledge is vital for someone who will start a business or business to understand customers from various perspectives ranging from social, cultural, environmental, economic, emotional, age, and many others. The goal of entrepreneurship is to be able to help the economy of a country and also the surrounding economy so that it can help create new jobs [4].

He believes entrepreneurship is a dynamic process to create additional wealth created by individuals who dare to take significant risks. Of course, with various conditions including reasonableness, time, and career commitment or providing value for multiple goods and services. The product services offered are not always new or unique, but the value of the goods will offer various opportunities for business actors [5].
The characteristics of entrepreneurship, according to researchers, one of which is having very high courage that does not care about what will happen, but cannot be separated from control because it is not only courageous but also has a reasonably good analysis of all elements of both the environment and technological progress. The others are good analysis and have a good leadership spirit. Then the high energy that also affects to continue to grow, innovation, innovation are things that have an essential role for an entrepreneur and continue to develop the business he runs and maintain tight competition with competitors.

\subsection{Product knowledge}

Product knowledge is more or less the same as market knowledge to whom we should sell products. Still, for products, we are usually more towards trends that are happening or booming; that's where we must immediately know which products are busy; if we as traders, we must understand what's going on. But on the other hand, some traders don't know which items are selling well in the market due to a lack of attention to the market and a lack of finding information about goods. Product knowledge is the knowledge-based knowledge in consumers' memory; the memory attached to consumers is knowledge of successful products. Products that can stick to a person's memory are by repeating each product continuously [6]

\subsection{Entrepreneurial knowledge}

Entrepreneurial knowledge is often known by every trader, one of which is that they never think about how their business can grow fast or have branches; this entrepreneurial knowledge factor is one of the reasons, this lack of knowledge makes them feel only to make ends meet. However, their chances could be more than they are today. Entrepreneurship is a highly innovative and creative ability used as the basis for driving success. The essence of entrepreneurship is our ability to create new, unique, and different things from others through creative and innovative ways to create opportunities. A person will succeed if he has the power, willingness, and is driven by knowledge [7].

\subsection{Understanding Performance}

Performance is a process that can be measured over a certain period based on a predetermined agreement according to [8]. Performance results from a job seen from the quality of work, working time, and cooperation to achieve the same goal [9]. Performance is the result of the achievements that have been made from specific tasks. Performance is the goal of the company's accomplishments to 
realize the acts that occur from each group and also individuals to get maximum results; performance is the result of a given task which is then done well and thoughtfully so that it gets top results, performance is the results of what is done by someone in carrying out tasks and will get results, with these results it can only be said to be performed because performance occurs. After all, some results have been done carelessly or in good seriousness [10].

\section{RESEARCH METHODS}

\subsection{Research Approach and Method}

Entrepreneurship is a broad knowledge of entrepreneurs who have creative and innovative ideas, the primary capital. A person who has an entrepreneurial spirit is a person who has a high leadership spirit, solid analytical skills such as in reading market share and products, increased selfconfidence, optimism about what will be achieved, never giving up in reaching targets, and discipline from all aspects to achieve goals. Achieved everything that had been planned and arranged.

[11] A person who has a strong desire and has a strong belief in entrepreneurship must be prepared to face uncertainty in running a business. Someone who has the readiness and strong desire to run entrepreneurship will be better than being ready to take all forms of risk but will increase if they get information about entrepreneurship.
This study uses a survey method to take samples and populations directly to the field. The technique used is the sampling technique. The tool used in this research is a questionnaire that consists of various questions. This research was conducted in Sukabumi Regency; this region is part of West Java Province. The population in this study is MSME actors who have businesses in the field of selling or trading necessities in the Sukabumi Regency. The number of respondents in this study was 200 grocery stores.

The answer to the purpose of this research is to analyze using SEM (Structural Equation Model)

through the Amos version 23 application and SPSS version 23. The data processed for this SEM analysis is data obtained from interviews in the field with the help of a questionnaire. The variables in this study are $\mathrm{X} 1$ to $\mathrm{Y}, \mathrm{X} 2$ to $\mathrm{Y}$, and $\mathrm{X} 3$ to $\mathrm{Y}$ and $\mathrm{X} 1, \mathrm{X} 2$, $\mathrm{X} 3$ to $\mathrm{Y}$.

\subsection{Types of Research}

The type used in this research is the quantitative type. [12] suggests that quantitative research is a research approach that uses a lot of numbers, starting from collecting data, interpreting the data obtained, and presenting the results.

\subsection{Research Framework}

From some of the explanations in the previous research above, the framework of thinking in this research is formed as follows:

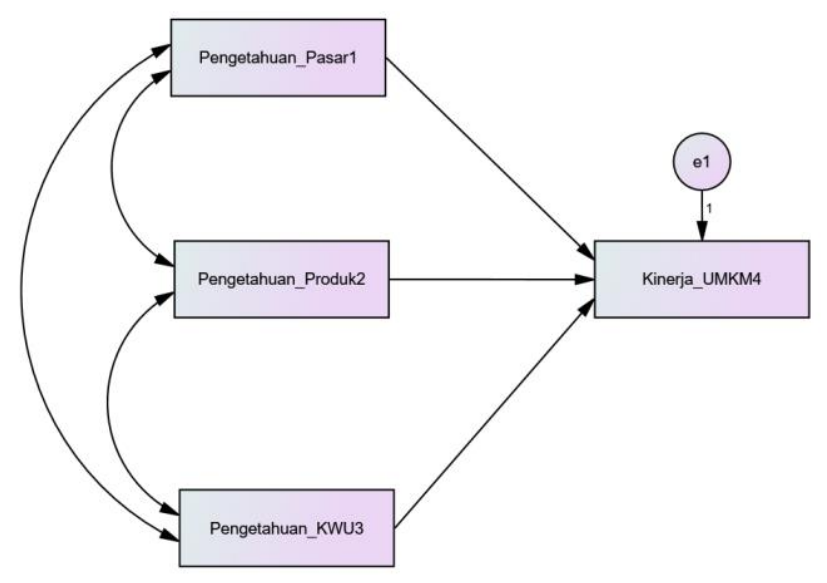

Figure 1. Research Framework

The MSMEs used in this study are MSMEs engaged in the primary food business running for more than three years in the Sukabumi Regency. This research has been carried out from March 2021 to November 2021, located in Sukabumi Regency, especially the Parung Kuda, Parakansalah, and Cidahu areas. Related to the research framework, where the sample in this study is basic food SMEs in 
Sukabumi Regency, which will identify whether or not their influence is mutual or not on the performance of UMKM in Sukabumi Regency, but before knowing that researchers need to conduct interviews directly with related parties. The method of using this questionnaire is to analyze which factors affect it by using SEM Amos and SPSS, or it can be called, in other terms, the crosscheck process so that the influencing factors match the actual conditions according to the results from the field.

\subsection{Research Sites}

This research was conducted in the Sukabumi Regency, West Java Province. The basis for choosing the location of this research is (1) the Geographical location of Sukabumi Regency, (2) Large primary food MSME resources, (3) Not yet entering basic food MSMEs to be superior.

\subsection{Observation}

Observation is the basis of all kinds of knowledge. Observation is a data collection technique and is carried out by conducting detailed and thorough research, and systematic recording [13]

\subsection{Interview}

According to [14], the interview is a process that will produce information and data that will be the key to research by holding questions and answers, the concept of face-to-face or face-to-face meetings between the interviewer and the respondent, with an interview guide as a tool in the process.

\subsection{Documentation}

Documentation includes static (photo) and dynamic (video) capture or recording, based on [15]

\subsection{Sample and Research Population}

According to [16], the population is a collection of individuals with predetermined qualities and characteristics. The population in this study were all basic food SMEs in the Sukabumi district.
In this study, multivariant analysis was used to compare the number of samples and the number of indicators. With several 1 in 5 to 10 [17] With this explanation, the researchers needed a minimum of 5 and a maximum of 10 samples for each indicator.

Respondents in this study were small business actors who were already in the form of clusters and registered with the UMKM Service and in the Sukabumi Regency area. The population is small business actors spread over the place, namely Sukabumi Regency (200 primary food businesses). The number of samples was determined using proportional sampling consisting of Sukabumi Regency; thus, the total number of pieces was 200 interview respondents where the researcher asked questions directly to get documentation information, to get more vital data, the researcher searched through books, the internet and looked for literature studies that had a relationship with the problem being studied.

\section{RESULT AND DISCUSSION}

\subsection{MSME Performance}

The performance of small, medium, and large MSMEs and their forms of business respondents in this study are essential to know and describe before the main discussion is explained. To analyze the performance of MSMEs in the Sukabumi Regency, researchers used as many as 200 respondents as primary food owners. All respondents in the study have met the criteria to become respondents in this study. This study collects information data contained in the questionnaire, which will be discussed below

\subsubsection{The Age of the Primary Food MSME Business Actors}

The age of the respondents is quite interesting from various age groups because no one dominates significantly; there is a significant difference in numbers between age groups, the age of 30-39 is indeed preferable. After all, the age in this group is indeed a productive age to run a business, one of which is basic food MSMEs.

\subsection{Samples and Research Data}

Table 1. Age of the Basic Food MSME

\begin{tabular}{|c|c|c|}
\hline Description & Amount & $\%$ \\
\hline $20-29$ Year & 35 & 17,5 \\
\hline $30-39$ Year & 73 & 36,5 \\
\hline $40-49$ Year & 65 & 32,5 \\
\hline $50-59$ Year & 23 & 11,5 \\
\hline
\end{tabular}




\begin{tabular}{|c|c|c|}
\hline $60-69$ Year & 4 & 2 \\
\hline Total & 200 & 100 \\
\hline
\end{tabular}

\subsubsection{Gender}

Gender is significant in conducting research, one of which is finding out and identifying its distribution in this study. After looking at the table below, it turns out that the male gender favours the majority; this means that it is pretty good because, with superior men, it means positive, which means that men have greater responsibilities in working and trying, which is the majority gender in the primary food MSME business.

Table 2. Gender

\begin{tabular}{|c|c|c|}
\hline Gender & Amount & $\%$ \\
\hline Male & 120 & 60 \\
\hline Female & 80 & 40 \\
\hline Total & 200 & 100 \\
\hline
\end{tabular}

\subsubsection{Level of education}

The level of education is critical to note because education is a very influential human resource in running a business in any midwife. Below are exciting results; it turns out that the primary food MSME business is still dominated by elementary-junior high school education.

Table 3. Level of Education

\begin{tabular}{|l|c|c|}
\hline \multicolumn{1}{|c|}{ School } & Amount & $\%$ \\
\hline $\begin{array}{l}\text { Elementary/junior high school } \\
\text { graduate }\end{array}$ & 96 & 48 \\
\hline $\begin{array}{l}\text { High school/vocational high } \\
\text { school graduates }\end{array}$ & 88 & 44 \\
\hline Diploma Graduate & 7 & 3,5 \\
\hline Graduate & 9 & 4,5 \\
\hline Total & 200 & 100 \\
\hline
\end{tabular}

\subsubsection{Business Length}

The length of business is a strength in doing business; the longer the business, the more it will determine the strength and mentality of business actors. The longer the business, the easier the level of success. However, not all of them are like that, in general, the age of businesses that are more than three years old and above have resilience in running a business. Below, the business age is 5-9 years, which is pretty good. Not easily shaken and not easily discouraged.

Table 4. Business Length

\begin{tabular}{|c|c|c|}
\hline Description & Amount & $\%$ \\
\hline 0-4 Year & 24 & 12 \\
\hline 5-9 Year & 89 & 44,5 \\
\hline 10-14 Year & 38 & 19 \\
\hline 15-19 Year & 26 & 13 \\
\hline 20-24 Year & 8 & 4 \\
\hline
\end{tabular}




\begin{tabular}{|c|c|c|}
\hline 25-29 Year & 9 & 4,5 \\
\hline $30-34$ Year & 4 & 2 \\
\hline $35-39$ Year & 1 & 0,5 \\
\hline$>40$ Year & 1 & 0,5 \\
\hline Total & 200 & 100 \\
\hline
\end{tabular}

\subsubsection{Source of Gross Income}

Income is significant to pay attention to in running a business because it is the main target in a company, namely getting income, so we can see from this study that gross income is more in the first place.

Table 5. Source of Gross Income

\begin{tabular}{|c|c|c|}
\hline \multicolumn{1}{|c|}{ Income } & Amount & $\%$ \\
\hline$<25.000 .000$ & 100 & 50 \\
\hline $25.000 .000-50.000 .000$ & 79 & 40 \\
\hline $51.000 .000-100.000000$ & 19 & 10 \\
\hline$>100.000000$ & 2 & 1 \\
\hline Total & 200 & 100 \\
\hline
\end{tabular}

\subsection{Result}

\subsubsection{Validity Test}

A validity Test is used to measure whether or not a questionnaire is valid. Based on the calculation of the validity of the authors using the SPSS version 23 program and then measured by comparing the value of $r$ count with $r$ table. If the $r$ count is greater than the $r$ table, then the question items are declared valid, and vice versa. The value of the $r$ table at a significant level of 5\% (0.05) is 0.235 . Based on the results of testing the validity of the questionnaire, the recapitulation of validity testing can be seen in the following table:

Table 6. Market Knowledge Validity Test

\begin{tabular}{|c|c|c|c|}
\hline No Item & rsy & r-table 5\%(200) & Information \\
\hline 1 & 640 & 0.138 & Valid \\
\hline 2 & 203 & 0.138 & Valid \\
\hline 3 & 292 & 0.138 & Valid \\
\hline 4 & 915 & 0.138 & Valid \\
\hline 5 & 477 & 0.138 & Valid \\
\hline 6 & 958 & 0.138 & Valid \\
\hline 7 & 958 & 0.138 & Valid \\
\hline 8 & 875 & 0.138 & Valid \\
\hline 9 & 158 & 0.138 & Valid \\
\hline 10 & 310 & 0.138 & Valid \\
\hline 11 & 237 & 0.138 & \\
\hline
\end{tabular}

The results on the validity of market knowledge are declared valid by the results above, 
with the results at the maximum limit being declared valid being 0.138 . In contrast, in this validity test exceeding the standard number, it is declared valid.

Table 7. Product Knowledge Validity Test

\begin{tabular}{|c|c|c|c|}
\hline $\begin{array}{c}\text { No } \\
\text { Item }\end{array}$ & rsy & r-table 5\%(200) & Information \\
\hline 1 & 565 & 0.138 & Valid \\
\hline 2 & 555 & 0.138 & Valid \\
\hline 3 & 956 & 0.138 & Valid \\
\hline 4 & 757 & 0.138 & Valid \\
\hline 5 & 351 & 0.138 & Valid \\
\hline 6 & 817 & 0.138 & Valid \\
\hline 7 & 194 & 0.138 & Valid \\
\hline 8 & 458 & 0.138 & Valid \\
\hline 9 & 458 & 0.138 & Valid \\
\hline
\end{tabular}

The results of the product knowledge validity test were declared valid from no. 1 to no. 9, which shows the numbers generated in this study exceed the predetermined standard numbers.

Table 8. Entrepreneurial Knowledge Validity Test

\begin{tabular}{|c|c|c|c|}
\hline $\begin{array}{c}\text { No } \\
\text { Item }\end{array}$ & rsy & r-table 5\%(200) & Information \\
\hline 1 & 031 & 0.138 & Invalid \\
\hline 2 & 143 & 0.138 & Valid \\
\hline 3 & 360 & 0.138 & Valid \\
\hline 4 & 667 & 0.138 & Valid \\
\hline 5 & 663 & 0.138 & Valid \\
\hline 6 & 858 & 0.138 & Valid \\
\hline 7 & 384 & 0.138 & Valid \\
\hline 8 & 264 & 0.138 & Valid \\
\hline 9 & 264 & 0.138 & Valid \\
\hline 10 & 819 & 0.138 & \\
\hline
\end{tabular}

Table 9. Validity Test

\begin{tabular}{|c|c|c|c|}
\hline Variable & Rsy & r-table 5\%(200) & Information \\
\hline X1 &, 814 & 0,138 & Reliable \\
\hline X2 &, 807 & 0,138 & Reliable \\
\hline X3 &, 832 & 0,138 & Reliable \\
\hline Y &, 853 & 0,138 & Reliable \\
\hline
\end{tabular}


The results of this validation test show that one question is not valid, meaning that in this case, there is no significant effect on the questions asked. This statement is supported by research [18], which states that all tests have been declared valid.

Table 10. MSME Performance Validity Test

\begin{tabular}{|c|c|c|c|}
\hline No Item & rsy & r-table 5\%(200) & Information \\
\hline 1 & 224 & 0.138 & Valid \\
\hline 2 & 082 & 0.138 & Valid \\
\hline 3 & 206 & 0.138 & Valid \\
\hline 4 & 567 & 0.138 & Valid \\
\hline 5 & 175 & 0.138 & Valid \\
\hline 6 & 793 & 0.138 & Valid \\
\hline 7 & 345 & 0.138 & Valid \\
\hline 8 & 606 & 0.138 & Valid \\
\hline 9 & 553 & 0.138 & Valid \\
\hline
\end{tabular}

The results of the SPSS Validation test with an $\mathrm{N}$ value of 200 ( $\mathrm{N}$ is the total of respondents). Looking at the table above, it can be concluded that all data from the $r$ table is declared valid because the results achieved can exceed the set limit of 138; with the results above, the $r$ table is clearly said to be good. This result is also supported by research [19] which states that it has a significant positive effect on the performance of MSMEs. What distinguishes the research is only the influence of knowledge.

\subsubsection{Reliability Test}

The alpha value is greater than the $r$ table, which is consistent, so this number is valid. The goal of this is consistency and reliability. After all the validation tests were completed using SPSS 23, the researchers continued the validation test using Amos 23.

\subsubsection{Validity test with Amos version 23}

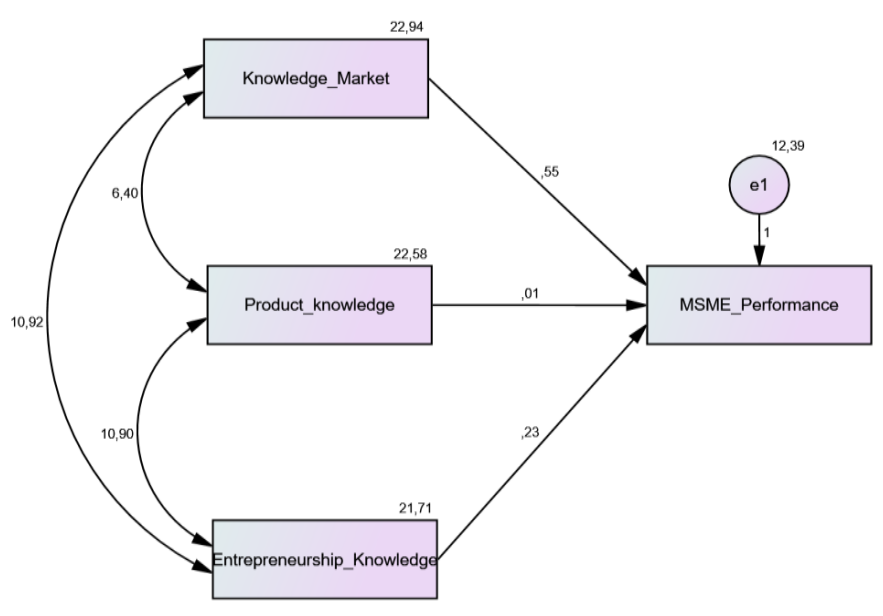

Figure 2. Flow development 
Table 11. Validation Research

\begin{tabular}{|l|c|}
\hline \multicolumn{2}{|l|}{ Standardized Regression Weights (Group number 1- Default Mode) } \\
\hline MSME Performance $\leftarrow$ Market Knowledge & Estimate \\
\hline MSME Performance $\leftarrow$ Product Knowledge &, 006 \\
\hline MSME Performance $\leftarrow$ Entrepreneurship Knowledge &, 226 \\
\hline
\end{tabular}

According to [20], Convergent Validity is known through the loading factor, so the expected value from the results of this test is $>0.7$. Meanwhile, according to [21], In addition to using the loading factor, convergent validity can also be known through AVE (Average Variance Extracted) with the condition that AVE $>0.5$.

The validity test results with the Convergent Validity test Addressing pretty good results from the three variables above, it turns out that product knowledge has a very significant effect because the value generated reaches 544, which means it exceeds the standard 0.5. In contrast, the impact of product knowledge can only get 006 which means it is still less than standard, while the effect of Entrepreneurship Knowledge can reach a value of 226. This result shows a significant impact on exceeding the middle, which is 0.5 .

From the results of the three above, it can be concluded that two are very significant and one is less influential, namely product knowledge.

Validation Test with CFA Test or Validation Test with Construction (Indicator)

Critical Ratio $(\mathrm{CR})>1.96$ with Probability $(\mathrm{P})<0.05$ Sign $* * *$ is Significant $<0.001$

Table 12. Regression Weights

\begin{tabular}{|l|c|c|c|c|}
\hline \multicolumn{5}{|c|}{ Regression Weights (Group number 1- Default Mode) } \\
\hline & Estimate & S.E. & C.R. & PLabel \\
\hline MSME Performance $\leftarrow$ Market Knowledge &, 549 &, 060 & 9,179 & ${ }^{* *}$ par_1 \\
\hline MSME Performance $\leftarrow$ Product Knowledge &, 006 &, 060 &, 097 &, 923 par_2 \\
\hline $\begin{array}{l}\text { MSME Performance } \leftarrow \text { Entrepreneurship } \\
\text { Knowledge }\end{array}$ &, 234 &, 068 & 3,457 & ${ }^{* * *}$ par_3 \\
\hline
\end{tabular}

According to [22] confirmatory factor analysis or often called Confirmatory Factor Analysis (CFA) is used to test the dimensionality of a constructor variable.

The results of the CFA test on market knowledge with a $\mathrm{CR}$ value exceeding the standard of the specified number, which means it has a very significant effect and can be seen from the $\mathrm{P}$ has an asterisk, the asterisk is a sign of significance. able to achieve from the standard number then the third effect of knowledge entrepreneurship has a significant value exceeding the specified standard. These results are also supported by research [23] which states with these results that all influence each other but what distinguishes the previous research is a competitive advantage.

\subsubsection{Validity test with Discriminant Test}

Meets the criteria if the Square Root Value of AVE must be higher than the Correlation Value between Laurent Variables and knowledge management on MSME performance.

Validity Test with Discriminant Test with Validity Meets the criteria if the Square Root Value of AVE must be higher than the Correlation Value between Laurent Variables 
Table 13. Validity Test with Discriminant Test

\begin{tabular}{|l|c|c|c|c|}
\hline & $\begin{array}{c}\text { Entrepreneurship } \\
\text { Knowledge }\end{array}$ & $\begin{array}{c}\text { Product } \\
\text { Knowledge }\end{array}$ & $\begin{array}{c}\text { Market } \\
\text { Knowledge }\end{array}$ & $\begin{array}{c}\text { MSME } \\
\text { Performance }\end{array}$ \\
\hline $\begin{array}{l}\text { Entrepreneurship } \\
\text { Knowledge }\end{array}$ & 21,713 & & \\
\hline Product Knowledge & 10,901 & 22,582 & & \\
\hline Market Knowledge & 10,916 & 6,403 & 22,941 & \\
\hline MSME Performance & 11,144 & 6,202 & 15,189 & 23,374 \\
\hline
\end{tabular}

Discriminant validity is the degree to which the measurement results of a concept can distinguish themselves from the results of other concepts. Theoretically, it must be different [24]. Seeing the test in this table is quite interesting because all the data in this result have positive results. all data in this test have significant results.

Table 14. Descriptive Statistics Summary

\begin{tabular}{|l|c|c|c|c|r|r|}
\hline \multicolumn{1}{|c|}{ Variable } & min & max & skew & \multicolumn{1}{c|}{ c.r. } & \multicolumn{1}{c|}{ Kurtosis } & \multicolumn{1}{c|}{ c.r. } \\
\hline $\begin{array}{l}\text { Entrepreneurship } \\
\text { Knowledge }\end{array}$ & 21,000 & 45,000 &,- 537 & $-3,101$ & 1,722 & 4,970 \\
\hline Product Knowledge & 24,000 & 54,000 &,- 137 &,- 790 &, 332 &, 960 \\
\hline Market Knowledge & 37,000 & 55,000 &,- 129 &,- 742 & $-1,020$ & $-2,945$ \\
\hline MSME Performance & 28,000 & 50,000 &,- 096 &,- 552 &,- 326 &,- 942 \\
\hline Multivariate & & & & & 8,259 & 8,429 \\
\hline
\end{tabular}

According to [25] the normality test can be seen from the car value (critical ratio) of the multivariate, where the data can be said to be normally distributed if it is at a significance level of 0.01 if the c.r value of multivariate, slope (skewness) or sharpness (kurtosis) is in the range value between 2.58. Seeing the test in this table is quite interesting because all the data in this result have positive results, which means that all the data in this test have significant results.
The coefficient of determination $\left(\mathrm{R}^{2}\right)$ essentially measures how far the model's ability to explain endogenous variation [25]. The results of the squared are the results of the overall analysis and how much influence it has on the performance of MSMEs, in this study, it is quite good with a value of $47 \%$ indicating that this influence is quite significant or is said to have an influence.

Table 15. Squared Multiple Correlations: (Groups member 1-Default model)

\begin{tabular}{|c|c|}
\hline & Estimate \\
\hline MSME_Performance & 0,470 \\
\hline
\end{tabular}

This statement is supported by the research of [26] which states that all data that is recapitulated or analyzed are classified with normal distribution results.

\section{CONCLUSION}

1) The results of the study show that most of the MSMEs for necessities are owned by men, with the last education being SD-SMP and aged 30 years and the length of the business has been running for 5 years.

2) Based on the results of SPSS, all data from the questionnaire have been tested for validation with the results of all data being declared valid beyond the standard limit.

3) Based on the results of SEM Amos version 23, market knowledge, product knowledge, and entrepreneurial knowledge have a positive and significant impact on the performance of SMEs. The influence of the 
product has a very significant effect on the performance of MSMEs as research in [27] which distinguishes in this study is buying interest, while in this study it is on the performance of MSMEs, which means it is more complex. The influence of market knowledge has a significant effect on the performance of MSMEs, but research [28] states that market knowledge has a negative effect and has no effect on marketing performance, this is due to the need for MSMEs to dig deeper to innovate, customer satisfaction, competitors and so on need to be considered. Again, that's what distinguishes this research.

Entrepreneurial entrepreneurship knowledge has a positive effect on the performance of SMEs. The results of this study are by research [29] which states that entrepreneurial orientation to competitive advantage has a significant positive effect, it is stated that the higher the entrepreneurial orientation of MSMEs, the higher the competitive advantage.

\section{SUGGESTION}

Each question that is asked to the respondent needs to be reviewed first, the researcher needs to understand more deeply the language in the field so that it can make it easier for the researcher. So the need for structured questions to make it easier for respondents and make it easier for researchers to find out market knowledge, product knowledge, and entrepreneurial entrepreneurship knowledge on MSME performance.

\section{REFERENCES}

[1] N. V. Feranita and H. A. Setiawan, "Peran Keunggulan Bersaing Dalam Memediasi Dampak Orientasi Pasar Dan Orientasi Kewirausahaan Terhadap Kinerja UMKM," Maj. Ilm. Dian Ilmu, vol. 18, no. 1, pp. 5470, 2019.

[2] T. W. Zimmerer and N. M. Scarborough, "Pengantar Kewirausahaan Dan Manajemen Bisnis Kecil (Edisi Bahasa Indonesia) Jakarta,” Jakarta PT. Rineka Cipta, 2002.

[3] R. I. L. Ginting, "Pengaruh Pengetahuan Kewirausahaan dan Karakteristik Kewirausahaan Terhadap Keberhasilan Usaha Kecil Menengah (UKM) di Kelurahan Karang Berombak," 2017.
[4] B. N. Kusuma, "Orientasi Pasar, Inovasi, Orientasi Teknologi, Dan Manajemen Pengetahuan Dalam Meningkatkan Kinerja Bisnis UMKM Di Soloraya." Universitas Muhammadiyah Surakarta, 2018.

[5] M. K. Nandakumar, A. Ghobadian, and N. O’Regan, "Business-level strategy and performance: The moderating effects of environment and structure," Manag. Decis., 2010.

[6] K. Shirin and H. H. Kambiz, "The effect of the country-of-origin image, product knowledge and product involvement on consumer purchase decisions," Chinese Bus. Rev., vol. 10, no. 8, 2011.

[7] S. Suryana and A. Jauhari, "Pengaruh Koordinasi Dan Pengendalian Terhadap Kinerja Pegawai (Studi Pada Dinas Bina Marga, Sumber Daya Air Dan Pertambangan Kabupaten Bandung Barat)," J. Ilm. Magister Adm., vol. 10, no. 1, 2020.

[8] N. Octaviani, D. Dasmadi, and U. R. Safitri, "Pengaruh Disiplin Kerja, Lingkungan Kerja Dan Kepuasan Kerja Terhadap Kinerja Karyawan Pt Sahabat Unggul Internasional Kabupaten Semarang," EKOBIS J. Ilmu Manaj. dan Akunt., vol. 9, no. 1, pp. 111-118, 2021.

[9] E. Sutrisno, "Manajemen sumber daya manusia," 2013.

[10] P. J. Simanjuntak, "Manajemen dan evaluasi kinerja," Language (Baltim)., vol. 17, no. 154 p, p. $18 \mathrm{~cm}, 2002$.

[11] M. Jailani, R. Rusdarti, and K. Sudarma, "Pengaruh kewirausahaan, motivasi belajar, sosial ekonomi orang tua dan selfefficacy terhadap minat berwirausaha siswa," J. Econ. Educ., vol. 6, no. 1, pp. 52-59, 2017.

[12] S. Arikunto, "Prosedur penelitian pendekatan praktek,” Jakarta: Rineka Cipta, 2006.

[13] A. Suharsimi, "Prosedur Penelitian Suatu Pendekatan Praktik Jakarta: PT,” Bina Akara, 1993.

[14] S. Siregar, "Statistika Terapan," 2017.

[15] M. S. Jasmail, "Perancangan Tutorial Baju Kaos Secara Manual." Universitas Negeri Makassar, 2018.

[16] N. A. Nazir, "Person-culture fit and employee commitment in banks," Vikalpa, vol. 30, no. 3, pp. 39-52, 2005. 
[17] J. F. Hair, C. M. Ringle, and M. Sarstedt, "PLS-SEM: Indeed a silver bullet," J. Mark. theory Pract., vol. 19, no. 2, pp. 139-152, 2011.

[18] J. Sanchaya Hendrawan and H. Sirine, "Pengaruh Sikap Mandiri, Motivasi, Pengetahuan Kewirausahaan Terhadap Minat Berwirausaha (Studi Kasus pada Mahasiswa FEB UKSW Konsentrasi Kewirausahaan)," AJIE-Asian J. Innov. Entrep., vol. 02, no. 03, pp. 291-292, 2017.

[19] R. F. N. Rahman and F. E. FE, "Pengaruh Modal, Pengetahuan, dan Inovasi terhadap Kinerja UMKM Kecamatan Karangrejo Kabupaten Tulungagung," Artik. Univ. Nusant. PGRI Kediri, vol. 1, no. 11, pp. 1-16, 2015.

[20] A. Widarjono, "Analisis multivariat terapan," Yogyakarta UPP STIM YKPN, 2015.

[21] I. Ghazali and H. Latan, "Partial Least Squares; Konsep, Tekhnik dan Aplikasi Menggunakan Program Smart PLS 3.0," Semarang: Badan Penerbit Undip, 2015.

[22] H. Latan, "Structural equation modeling: Konsep dan aplikasi menggunakan program LISREL 8.80,” Bandung Alf., 2012.

[23] M. Maharani, H. Maupa, and A. Aswan, "Knowledge Management Dan Aspek Kewirausahaan Terhadap Kinerja Melalui Keunggulan Bersaing Ukm Di Kota
Makassar," Hasanuddin J. Appl. Bus. Entrep., vol. 3, no. 1, pp. 27-35, 2020, doi: 10.26487/hjabe.v3i1.294.

[24] P. Bambang and L. M. Jannah, "Metode Penelitian Kuantitatif: Teori dan Aplikasi," Jakarta Graf., 2005.

[25] I. Ghozali, "Structural Equation Modelling, Edisi II,” Semarang Univ. Diponegoro, 2008.

[26] W. Hidayat, W. Widiartanto, A. E. Prihartini, and R. S. Dewi, "Model Pengembangan Pasar Tradisional Berbasis Pada Perilaku Konsumen," J. Adm. Bisnis, vol. 7, no. 2, p. 108, 2018, doi: 10.14710/jab.v7i2.22696.

[27] O. Irvanto and S. Sujana, "Pengaruh Desain Produk, Pengetahuan Produk, Dan Kesadaran Merek Terhadap Minat Beli Produk Eiger,” J. Ilm. Manaj. Kesatuan, vol. 8, no. 2, pp. 105126, 2020, doi: 10.37641/jimkes.v8i2.331.

[28] F. Zaricha, "Pengaruh Pengetahuan Pemasaran, Orientasi Pasar, Dan Kapabilitas Pemasaran Terhadap Kinerja Pemasaran Padausaha Mikro Kecil Menengah (Umkm) Di Kecamatan Gresik Kabupaten Gresik." Universitas Muhammadiyah Gresik, 2018.

[29] A. LATIFAH, "Pengaruh Orientasi Pasar, Orientasi Kewirausahaan, Dan Manajemen Pengetahuan Terhadap Keunggulan Bersaing Umkm Di Masa Pandemi (Studi Pada Umkm Di Kabupaten Kendal)." 